\title{
CUSTOMER COMPLAINT RESPONSE STRATEGY IN SERVICE FAILURE: STUDY OF ONLINE SHOPPER IN INDONESIA
}

\author{
Yeshika Alversia ${ }^{1 *}$ and Rizky Wijayanti ${ }^{2}$ \\ ${ }^{1,2}$ Universitas Indonesia, Depok, Indonesia
}

\begin{abstract}
The shifting pattern of shopping habit into a digital nowadays perceived by the business players as the trigger of the growth in e-commerce and e-marketplace. Indonesia is currently one of the largest markets in Southeast Asia for online shopping. On the other hand, it is inevitable that there are still many obstacles and problems that defer the optimized growth of e-marketplace in Indonesia. There are customer concerns about issues that may arise when they do online shopping. Service failures that often arise eventually encourage customers to complain. Failure in service that lead to the emergence of various complaints from customers is an inevitable thing. Each company must prepare an optimal strategy to manage those complaints. The objective of this research is to find out whether there is a difference effect of service failure explanation in the form of excuse, justification, reference and apology on customer satisfaction and repurchase, in the high level of problem condition compared to the low level of problem condition, for the case of online shopper e-marketplace in Indonesia. Furthermore, this research is conducted with the purpose to build the best strategy of giving response using service failure explanation (i.e. excuse, justification, reference and apology). Researchers use a scenario-based experiment as the method and then all the data were analysed using T-test and ANOVA. Total 325 respondents of online shoppers in Indonesia were collected, and the results revealed that apology and justification are the best choices for responding customers' complaints.
\end{abstract}

Keywords: Customer Complaint, E-Commerce, Online Shopper, Response Strategy, Service Failure Explanation

\section{INTRODUCTION}

The high level of internet users has contributed greatly to the changing ways of shopping for Indonesians today. There is shifting in style of shopping among Indonesians, from offline to online. In 2014, based on The Nielsen Global Survey of ECommerce, concluded that $61 \%$ of Indonesian use mobile phones for online shopping. In addition, Indonesia, together with the Philippines, Thailand and Vietnam, is in the top position in global for the country with high amount of consumers who do online shopping from mobile phones. This phenomenon eventually led to the emergence of a variety of e-marketplaces in Indonesia ranging from Bukalapak, Elevania, Jd.ID, Tokopedia, Shopee, Blanja, BliBli, and others, that finally opened up opportunities for many businesses to open their stores with an online system.

E-marketplace and e-commerce provide opportunities for electronic channel transactions, which are generally known as internet-based platforms. There are several types of e-marketplaces that move in different scopes, such as resources, foods, pharmacueticals, or those that support various types of transactions such as B2B, customer-to-customer, and business-to-customer (Standing \& Standing, 2015). It is inevitable that there are still many obstacles and problems that cause the growth of Indonesia's e-marketplace cannot be maximized. From the consumer side, there are still many concerns and problems when people shop online. Key concerns include transaction fraud, online payment security, and product quality that is not in line with

* Corresponding author. Email address: yeshika@ui.ac.id 
image promotion. This can trigger dissatisfaction or service failure by the emarketplace (service failure) which ultimately encourages consumers or the public to make complaints or complaints.

Previous study states that it is estimated that $15 \%-25 \%$ of consumers experience dissatisfaction from their shopping activities, even though the cause of complaint occur in various types of product categories (Andreasen, 1988). Koushiki (2013) argues that several studies that have been done before prove that if companies make explanation they are able to overcome service failure problems. Furthermore, Suveera (2014) in Tarofder et al., (2016), explains that there are still few number of studies that prove service failure explanation is able to provide significant influence on customer satisfaction and repurchase intention.

To help prevent the emergence of negative effects from complaints that arise, companies must be able to create a good customer service system. The existence of this current research is expected to have a positive impact from the response that will be given by company or e-marketplace to the customer after they feel the service failure and then get an explanation, whether excuse, justification, reference and apology. Therefore, the objectives of this study are as follow: To find out whether there is a difference effect of service failure explanation in the form of excuse, justification, reference and apology on customer satisfaction and repurchase in the high level of problem condition compared to the low level of problem condition for the case of online shopper e-marketplace in Indonesia.

\section{LITERATURE REVIEW AND HYPOTHESES DEVELOPMENT}

\subsection{Service Failure and Level of Failure}

Service failure is defined as the perception received by the customer, when one or more of the aspects of service provided in a transaction activity process is not in accordance with their expectations (Lovelock \& Wirtz, 2011). Further, Lovelock and Wirtz (2011) explained that in addressing the failure, there are several actions that might be carried out by the customer, including: (1) Take a public action; the customer may take action by making a complaint to the company directly, or the authorities, such as to a third party or police, organizations, or other legal assistance. (2) Private action; the customer takes personal actions, meaning that it does not report to a third party, but personally the customer will blacklist the company or service provider that gives bad service to them. (3) Take no action; mostly happened, that is, the customer does not even complain despite getting unsatisfactory service. From previous research, it is proven that only $5 \%-10 \%$ of the total unhappy customer (customers who get less satisfactory service) whose finally give their complain.

Level of failure is the extent to which customer satisfaction in a service recovery depends on the severity of the problem and recoverability that can be given (Lovelock \& Wirtz, 2011). The level of problems when a failure occurs can be explained into two groups of problem levels; heavy or high level of problem and light or low level of problem. At the level of severe problems it is actually very difficult to do recovery which can completely satisfy the customer, for example, it is very difficult to recover from customers who are injured due to service equipment errors. There is a concept that explains "let the punishment fit the crime" means that the customer will expect low when there is an error or failure that is small (minor) and vice versa. Customers will expect recovery and even significant compensation when a major error occurs or major failure in terms of time, effort, causing high irritation, or anxiety because of service failures (Lovelock \& Wirtz, 2011).

\subsection{Service Recovery}

Service recovery is a systematic effort carried out by a company or service provider when a service failure has occurred in an attempt to resolve the problem and keep the customer from using the same company (Lovelock \& Wirtz, 2011). There are two general types of service recovery, namely Compensatory and Non-Compensatory Service Recovery. 
Compensation is one of the recovery strategies that proven has effective impact to improve the perspective of consumers when a service failure occurs (Bitner et al., 1990; Smith et al., 1999; Smith and Bolton, 1998 in Baker \& Mayer, 2014). In addition, compensation is the second most strategy that is used as one of the recovery initiatives in restaurants (Hoffman et al., 1995). Rust \& Chung, (2006) and Tax et al., (1998) explain that it is important for service providers to better understand non-compensatory recovery methods. One form of non-compensatory recovey is to provide adequate information to consumers on the consideration of failure that has occurred by giving the explanation (Baker \& Meyer, 2014).

2.3. Service Failure Explanation

Bies (1987) on Tarofder et al., (2016) states that there are four parts of explanation classification as a form to handle service failure, this classification are as follow: (1) Excuse: one of the ways used by a company to explain the problem due to external problems. In this case the company tends to try to avoid responsibility for the problems that faced by their customers. (2) Justification; one of the methods used by the company in dealing with customer complaints, almost same with excuse, both methods show that the problem arises because of the company's external factors. However, justification shows that the company accepts the responsibility and will improve it. In this case the service problem or failure must be justified. (3) Reference; one method of managing problems from customers, by way of companies comparing situations experienced by one customer with another customer who has experienced worse service problems. It turns out that this way can reduce negative perception because of the service failure. (4) Apology; embodiment of regret from the company for service failures that occur. The company acknowledges that the problems that arise are the responsibility of the company and offer an apology indeed it is felt necessary in every case that arises.

\subsection{Customer Satisfaction}

Satisfaction is defined as a positive attitude based on the experience of using a service or product (Tarofder et al., 2016). Generally, customers have a prediction of the service they will feel before consuming a product or services. Predictions that arise as a result of the search process for product / service information (search and choice process) before finally deciding to use it (Lovelock \& Wirtz, 2011). According to Kristen et al., (2014) on Tarofder et al., (2016) differences in the types of service failures that exist and ensuring service recovery can affect customer satisfaction and future intentions.

\subsection{Repurchase Intention}

Many studies have proven that when failures occur in company services, customers will tend to spread negative word of mouth (NWOM) and do not want to repurchase similar products (Mikael, 2013; Beth et.al., 2010 on Tarofder et.al ., 2016). The effort given by the company to carry out recovery on the problems that occur is able to provide a positive influence on repurchase intention (Goodwin \& Rose, 1992; Kelley et.al., 1994 on Tarofder et al., 2016). When a problem or complaint is wellhandled by the company and give satisfaction there will appear a greater chance that the customer will remain loyal and use the same product or service. Complaint handling should be seen by the company as a profit center rather than cost center. If customers who feel dissatisfied fail to be handled, then the company will lose more than just the value of transactions in the future (Lovelock \& Wirtz, 2011).

Based on the above explanation, the hypotheses of this study are as follow:

-The effect of excuse on customer satisfaction and repurchase intention

H1A : When company using excuse as the response, there is a significant difference in customer satisfaction between conditions of high level of problem and low level of problem.

H1B : When company using excuse as the response, there is a significant difference in purchase intention between conditions of high level of problem and low level of problem. 
-The effect of justification on customer satisfaction and repurchase intention.

H2A : When company using justification as the response, there is a significant difference in customer satisfaction between conditions of high level of problem and low level of problem.

H2B : When company using justification as the response, there is a significant difference in repurchase intention between conditions of high level of problem and low level of problem.

-The effect of reference on customer satisfaction and repurchase intention.

H3A : When company using reference as the response, there is a significant difference in customer satisfaction between conditions of high level of problem and low level of problem.

H3B : When company using reference as the response, there is a significant difference in repurchase intention between conditions of high level of problem and low level of problem.

-The effect of apology on customer satisfaction and repurchase intention.

H4A : When company using apology as the response, there is a significant difference in customer satisfaction between conditions of high level of problem and low level of problem.

H4B : When company using apology as the response, there is a significant difference in repurchase intention between conditions of high level of problem and low level of problem.

\section{RESEARCH METHODOLOGY}

\subsection{Research Design}

This research is conducted using experimental design with factorial design. Factorial used to see the differences if there is interaction between two cells. Therefore this research is in the form of 4 (type of service failure explanation) x 2 (level of problem) as illustrated in the following table:

Table 1 Experimental Factorial Design $4 \times 2$

\begin{tabular}{ccc}
\hline Service Failure Explanation & \multicolumn{2}{c}{ Level of Problem } \\
& Low & High \\
\hline Excuse & cell A & cell B \\
Justification & cell C & cell D \\
Reference & cell E & cell F \\
Apology & cell G & cell H \\
\hline \multicolumn{2}{c}{ Source: data processed by researchers (2018) }
\end{tabular}

This experiment was carried out by giving eight different stimulus to the respondents, therefore it has eight cells, specifically:

Cell A: Respondents who receive stimulus in the form of conditions when shopping in e-marketplace facing low level of problem category then make a complaint and get an excuse-response.

Cell B: Respondents who receive stimulus in the form of conditions when shopping in e-marketplace facing high level of problem category then make a complaint and get an excuse-response.

Cell C: Respondents who receive stimulus in the form of conditions when shopping in e-marketplace facing low level of problem category then make a complaint and get a justification-response. 
Cell D: Respondents who receive stimulus in the form of conditions when shopping in e-marketplace facing high level of problem category then make a complaint and get a justification-response.

Cell E: Respondents who receive stimulus in the form of conditions when shopping in e-marketplace facing low level of problem category then make a complaint and get a reference-response.

Cell F: Respondents who receive a stimulus in the form of conditions when shopping in e-marketplace facing high level of problem category then make a complaint and get a reference-response.

Cell G: Respondents who receive stimulus in the form of conditions when shopping in e-marketplace facing low level of problem category then make a complaint and get an apology-response.

Cell H: Respondents who receive stimulus in the form of conditions when shopping in e-marketplace facing high level of problem category then make a complaint and get an apology-response.

\subsection{Data collection method}

In primary data collection, researchers created a scenario-based experiment in the form of a self-administered questionnaire distributed online through email and social media. For the experimental design, the minimum sample size required is 30 people per cell (Malhotra, 2010), therefore, the researchers aim to collect a minimum of 240 respondents for total eight cells. The questionnaire used the google form feature for respondents who met the criteria, then fill it independently. In addition, the questions given are structured questionnaires where the choice of answers to the questions given has been determined by the researchers. In this study, the sampling technique used nonprobability sampling through convience sampling, i.e. the sample will be taken based on certain considerations that are considered in accordance with the research objectives and the desired characteristics of the sample. Researchers spread the link of online questionnaire through email and friends' list on social media. This method is used by looking at the ease and readiness of the sample to be chosen as research respondents.

Manipulation check was also performed in this study. For experimental research, there are requirements that must be met so that the data obtained can be processed. Manipulation check is emphasized to find out whether the stimulus in the form of online shopping scenarios is understood by the respondents. There are eight different scenarios, regarding the two level of problem (i.e. high level and low level of problem) and four types of the responses presented to those complaints in the form of excuse, justification, reference or apology. In this case, only the data from respondents whose answer are corresponded to the manipulation check questions used to be processed in the study.

Population of this study are people who have done online shopping in one of the e-marketplaces in Indonesia, whether they have or have never complained online, and have a domicile in the Java Island with the age range of the millennial generation, 1838 years old. In this study the total number of respondents obtained who met the criteria and passed the manipulation check was 325 people. The total respondents were divided into 8 different groups who filled out 8 questionnaires with a stimulus in the form of different scenarios that had been distributed online. 
AFEBI Management and Business Review (AMBR)

Vol.04 No.01, June 2019

Table 2 Distribution of Respondents for Each Type of Questionnaire

\begin{tabular}{|c|c|c|}
\hline No & Questionnaires & Number of Respondents \\
\hline 1 & Excuse on high level of problem condition & 39 \\
\hline 2 & Excuse on low level of problem condition & 40 \\
\hline 3 & $\begin{array}{l}\text { Justification on high level of problem } \\
\text { condition }\end{array}$ & 38 \\
\hline 4 & $\begin{array}{l}\text { Justification on low level of problem } \\
\text { condition }\end{array}$ & 42 \\
\hline 5 & Reference on high level of problem condition & 49 \\
\hline 6 & Reference on low level of problem condition & 39 \\
\hline 7 & Apology on high level of problem condition & 42 \\
\hline 8 & Apology on low level of problem condition & 36 \\
\hline
\end{tabular}

Source: data processed by researchers (2018)

\section{RESULTS}

The next stage of processing research data is to test hypotheses. Hypothesis testing was carried out using independent t-test to see the mean differences between two different and unrelated sample groups. In testing with this method, there are some indicators used to determine the results of data processing. In the Lavene's Test for Equality of Variance section, if the significance value is $<0.05$, to determine the significance of the test independent t-test uses a column in the equal variance not assumed. Whereas if the significance of Lavene's Test for Equality of Variance is> 0.05 , the determination of the independent t-test test results uses a column on equal variance assumed (Malhotra, 2010).

Further, hypothesis testing is done to see the difference in the effect of the service failure explanation response in the form of excuse, justification, reference, and apology in conditions of high level of problem and low level of problem on customer satisfaction and repurchase intention.

\subsection{The Effect of Excuse, Justification, Reference and Apology on Customer Satisfaction}

Table 3 below shows the summary of the results related to the impact on customer satisfaction. Based on the results, the independent t-test test for customer satisfaction given excuse response shows that the value of the t-value is -2.401 with a significance value of 0.019 ( $\mathrm{p}$-value $<0.05$ ). With these results, it can be interpreted that customer satisfaction value generated by giving responses in the form of excuse has a significant difference, between conditions of high level of problem with low level of problem (MExHL $=2.442<$ MExLL $=3.075, \mathrm{p}$ value $<0.05,2$-tailed). So, from this test it can be concluded that hypothesis $1 \mathrm{~A}$ is accepted.

The independent $\mathrm{t}$-test test for customer satisfaction given justification response shows that the t-value obtained is -3.526 and the significance is 0.001 (p-value $<0.05$ ). The test results prove that there is a significant difference in the value of customer satisfaction when giving a justification response between conditions of high level of problem and low level of problem (MJustHL $=4.086<$ MJustLL $=4.88$, p-value $<0.05$, sig 2-tailed) Thus, it can be concluded that hypothesis $\mathbf{2 A}$ is accepted. 
Table 3 Mean difference between groups on Customer Satisfaction variable

\begin{tabular}{|c|c|c|c|c|c|c|c|c|}
\hline Hypothesis & Group & Mean & Group & Mean & $\begin{array}{c}\text { Mean } \\
\text { Difference }\end{array}$ & $t$-value & $\begin{array}{l}\text { Sig. (2- } \\
\text { tailed) }\end{array}$ & Result \\
\hline $\mathrm{H} 1 \mathrm{~A}$ & $\begin{array}{c}\text { Excuse-High } \\
\text { level of } \\
\text { problem }\end{array}$ & 2.442 & $\begin{array}{l}\text { Excuse-Low } \\
\text { level of } \\
\text { problem }\end{array}$ & 3.075 & 0.633 & -2.401 & 0.019 & Accepted \\
\hline $\mathrm{H} 2 \mathrm{~A}$ & $\begin{array}{l}\text { Justification- } \\
\text { High level of } \\
\text { problem }\end{array}$ & 4.086 & $\begin{array}{l}\text { Justification- } \\
\text { Low level of } \\
\text { problem }\end{array}$ & 4.881 & 0.795 & -3.526 & 0.001 & Accepted \\
\hline $\mathrm{H} 3 \mathrm{~A}$ & $\begin{array}{l}\text { Reference- } \\
\text { High level of } \\
\text { problem }\end{array}$ & 2.316 & $\begin{array}{l}\text { Reference- } \\
\text { Low level of } \\
\text { problem }\end{array}$ & 4.051 & 1.735 & -5.630 & 0.000 & Accepted \\
\hline $\mathrm{H} 4 \mathrm{~A}$ & $\begin{array}{c}\text { Apology-High } \\
\text { level of } \\
\text { problem } \\
\end{array}$ & 3.988 & $\begin{array}{c}\text { Apology-Low } \\
\text { level of } \\
\text { problem }\end{array}$ & 4.597 & 0.609 & -3.261 & 0.002 & Accepted \\
\hline
\end{tabular}

Source: data processed by researchers (2018)

Furthermore, for the reference response on customer satisfaction, it is known that the $t$-value obtained is -5.630 with a significance value of 0.000 ( $p$-value $<0.05$ ). Then from the test results, it can be explained that there is a significant difference between the response in the form of a reference to the condition of high level of problem with a response in the form of a high level of problem for customer satisfaction variables, (MRefHL $=2.490<$ MRefLL $=3.532$, p- value $<0.05$, sig 2-tailed). That way, it was concluded that hypothesis $3 \mathrm{~A}$ is accepted.

Finally, the independent t-test test for customer satisfaction given apology response shows that the results of the t-value were -3.261 and the significance value was 0.002 ( $p$-value 0.05). These results indicate that there is a significant difference in customer satisfaction between the response in the form of apology at high level of problem condition with a response in the form of apology at low level of problem $(\mathrm{MApHL}=3.988<\mathrm{MApLL}=4.597$, p-value $<0.05$, sig 2-tailed). Then it can be concluded that hypothesis $4 \mathrm{~A}$ is accepted.

\subsection{The Effect of Excuse, Justification, Reference and Apology on Repurchase Intention}

Table 4 below shows the summary of the results related to the impact on repurchase intention. Similarly, repurchase intention was tested by independent t-test. Based on the results, the independent t-test for repurchase intention given excuse response shows the $t$-value of the two groups was -2.693 and for the significance value obtained was 0.009 ( $p$-value <0.05). These results indicate that the value of the repurchase intention obtained in the form of an excuse response has a significant difference between the conditions of high level of problem and low level of problem $(\mathrm{MExHL}=2.596<$ MExLL $=3.300$, p-value $<0.05,2$-tailed ). Therefore, with these results it can be concluded that the hypothesis $1 \mathrm{~B}$ is accepted.

The next test was the independent t-test for repurchase intention given justification response, shows that the t-value obtained for both groups is -2.445 and the significance value is 0.017 . Based on these results it can be explained that there are significant differences in the two sample groups that have a justification response in conditions of high level of problem and group with a justification response at a low level of problem condition (MJustHL $=3.474<$ MJustLL $=4.048$, p-value $<0,05$, sig 2-tailed). Then it can be said that the hypothesis $2 B$ is accepted.

Furthermore, for the reference response on repurchase intention variables, the results of the t-value of -3.852 and a significance value of 0.000 (p-value 0.05 ). From these results it can be explained that there are significant differences in the form of a reference response to the condition of high level of problem by giving a reference response in the condition of high level of problem to respurchase intention (MRefHL $=3.411<$ MRefLL $=4.049$, p-value 0.05 , sig 2-tailed). Thus it can be concluded that hypothesis $3 B$ is accepted. 
AFEBI Management and Business Review (AMBR)

Vol.04 No.01, June 2019

Table 4 Mean difference between groups on Repurchase Intention variable

\begin{tabular}{|c|c|c|c|c|c|c|c|c|}
\hline Hypothesis & Group & Mean & Group & Mean & $\begin{array}{c}\text { Mean } \\
\text { Difference }\end{array}$ & $\begin{array}{c}t- \\
\text { value }\end{array}$ & $\begin{array}{l}\text { Sig. (2- } \\
\text { tailed) }\end{array}$ & Result \\
\hline H1B & $\begin{array}{l}\text { Excuse-High } \\
\text { level of } \\
\text { problem }\end{array}$ & 2.596 & $\begin{array}{l}\text { Excuse-Low } \\
\text { level of } \\
\text { problem }\end{array}$ & 3.300 & 0.731 & -2.693 & 0.009 & Accepted \\
\hline $\mathrm{H} 2 \mathrm{~B}$ & $\begin{array}{l}\text { Justification- } \\
\text { High level of } \\
\text { problem }\end{array}$ & 3.474 & $\begin{array}{l}\text { Justification } \\
\text {-Low level } \\
\text { of problem }\end{array}$ & 4.048 & 0.574 & -2.445 & 0.017 & Accepted \\
\hline $\mathrm{H} 3 \mathrm{~B}$ & $\begin{array}{l}\text { Reference- } \\
\text { High level of } \\
\text { problem } \\
\text { Apology- }\end{array}$ & 2.490 & $\begin{array}{l}\text { Reference- } \\
\text { Low level of } \\
\text { problem } \\
\text { Apology- }\end{array}$ & 3.532 & 1.042 & -3.852 & 0.000 & Accepted \\
\hline $\mathrm{H} 4 \mathrm{~B}$ & $\begin{array}{l}\text { High level of } \\
\text { problem }\end{array}$ & 3.411 & $\begin{array}{l}\text { Low level of } \\
\text { problem }\end{array}$ & 4.049 & 0.638 & -2.627 & 0.010 & Accepted \\
\hline
\end{tabular}

Source: data processed by researchers (2018)

Finally, the independent t-test for repurchase intention given apology response shows that the value of the t-value obtained was -2.67 with a significance value of 0.010 ( $p$-value $<0.05$ ). Based on the results of the test it can be said that there is a significant difference between the response in the form of apology at high level of problem with the response in the form of apology at low level of problem to repurchase intention variable $(\mathrm{MApHL}=3.411<\mathrm{MApLL}=4.049$, $\mathrm{p}$-value $<0.05$, sig 2-tailed). Then it can be concluded that hypothesis $4 \mathrm{~B}$ is accepted.

\section{DISCUSSION}

In influencing both customer satisfaction as well as repurchase intention, the justification response is still the best choice proven justification has the highest average value for both problem conditions, high level of problem and low level of problem. Wang et al., (2014) on Tarofder et al., (2016) explained that from the studies conducted, the response was in the form of justification in which there was a sense of responsibility for the problems or failures that occurred, more well received by the customer and giving a more positive impact on customer satisfaction and the level of repurchase intention. After justification, apology occupies the second position with an average value under justification. Both, justification and apology, have a fairly high average in conditions of high level of problem and low level of problem. The use of apology can also reduce bad influences such as negative word of mouth appearing due to service failure (Nguyen and McColl-Kennedy 2003, in Tarofder et al., 2016).

On reference and excuse, the average value produced is lower than justification and apology. Influence on customer satisfaction and repurchase intention for reference is also still greater at a low level of problem condition compared to high level of problem. This is because at a mild level of problem conditions, customers will feel more relieved when they get an explanation that there are still other customers who have problems or complaints that are heavier and worse. The same is true with excuse, when a problem or service failure appears but the e-marketplace does not have the intention to be responsible and does not acknowledge the error that the customer satisfaction value will decrease. According to Conlon and Murray (1996) on Tarofder et. Al., (2016), using excuse can increase customers' negative perception of a company or e-marketplace and not providing a form of responsibility will also produce a bad response from the customer.

\section{CONCLUSION AND IMPLICATIONS}

Overall, from results analysis of the research that has been done, the following conclusions are drawn: 
1. Giving response or explanation in the form of excuse, justification, reference and apology gives a different influence on customer satisfaction and repurchase intention both on the condition of a high level of problem or on a low level of problem.

2. Based on the results, the different influences of each explanation given, justification and apology do not have a significant difference in the effect on customer satisfaction and repurchase intention, both responses will have an equally positive or high mean value, or in other words, will give a high level satisfaction and repurchase intention from customer. Likewise with reference and excuse, in general they give results that are not significantly different between customer satisfaction and repurchase intention, both responses will equally give a low level satisfaction and repurchase intention.

3. In the condition of both low level and high level of problems, the service failure explanation in the form of justification has the greatest impact compared to other responses such as excuse, reference and apology. This shows that customers will be more satisfied and increase their repurchase intention, when the business provider or e-marketplace is able to provide a detailed explanation of the reasons why the problem can occur and the form of responsibility for the problems that arise. So that the justification response provides positive outcomes for customer satisfaction and repurchase intention. Meanwhile, excuse get the lowest average value results in both problem level conditions compared to apology and reference.

The implications for the company, in this case e-marketplace in Indonesia such as Tokopedia, Blibli.com or Lazada, are suggested as follow:

1. The form of service failure explanation provided by e-marketplace, whether excuse, justification, reference and apology can give a different influence on customer response, especially customer satisfaction and willingness to keep using the same e-marketplace in the future. For managers of the e-markeplace industry, at least use apology as the form of response and apology must be conveyed to the customer when complaining. Roschk and Susanne Kaiser (2013) explained that the use of apologies that are well conveyed to customers will have a good influence on the failure process that occurs (eg, social losses that arise due to spending that will be used for payment, or failed to be delivered). on the outcome of the failure that occurred (loss suffered by the customer because the item purchased was damaged). Therefore an apology needs to be reviewed in terms of providing an explanation of the complaint. Apology can reduce customers anxiety due to failures that occur and is proven that e-marketplace wants to address the problems (Boshoff and Leong, 2003 in Tarofder et al., 2016). Furthermore, e-marketplace also can use an apology and justification in providing complete response to the customer who complains, both to positively influence customer satisfaction and buy back the customer's purchase intention. Especially with the e-marketplace justification that can show the responsibility there is a failure, therefore customers will give their trust and keep using the same e-marketplace.

2. Avoid using excuse in responding when complaints arise which can damage the image of e-marketplace in front of customers by explaining that e-marketplace is not responsible. Previous studies have explained that angry customers will evaluate the excuse response as an unpleasant response (Tax et, al., 1998 on Tarofder et al., 2016). E-marketplace must be able to show empathy and show an effort to fix the problems that arise.

3. The e-marketplace can make a clear SOP (Standard Operating Procedure) for the seller as a partner of the e-marketplace and also for their customer service staff. Based on the this research, $41 \%$ of the total respondents, they admitted having complained to the e-marketplace and $62.7 \%$ of the respondents who made the complaint, submitted their complaints through the customer service in the emarketplace that was not directly complain to the seller. Therefore the management 
interacts well and needs to make a strict SOP in terms of treating customers and providing compilation responses that appear. This standard also needs to be given to sellers who are the partner of e-marketplace that allows for consistency of services to handle service failures.

4. Providing fast service failure response and in accordance with the conditions faced by the customer can be an alternative before the e-marketplace provides another form of service recovery in the form of material (e.g. money compensation) for severe failure conditions, which sometimes takes long time to be processed. By providing high-quality explanations that are fast and satisfying when a complaint arises, it will reduce the disappointment of the customer and keep the customer making purchases in the same e-marketplace.

5. Make prevention efforts, by providing additional services to customers that make it easier when conditions arise that require customers to complain. There are still very few e-marketplaces that provide additional complain services. Zalora, Lazada, and Blibli are the examples, blibli.com is one of the e-marketplaces that has a standard in handling complaints in the form of returning goods if the goods are known to be defect / not suitable or cannot be used (damaged). Blibli.com automatically provides a form that they put into the box along with the shopping items ordered by the customer. This form is standardized and contains complete information making it easier for customers if suddenly the damaged goods condition appears that requires the customer to return them. This was anticipated by the management of blibli.com and as a form of quick handling when complaints arose. This provided form also creates a positive perspective on customers that blibli.com is a trusted and professional e-marketplace in providing online shopping services. This form of SOP can be used as a reference by other e-marketplaces so that they can maintain their customer's trust.

\section{References}

Andreasen, A.R. (1988). Consumer complaints and redress: what we know and what we don't know. The Frontier of Research in the Consumer Interest. Proceedings of the International Conference on Research in the Consumer Interest, August, 675-722.

Baker, T.L., Meyer, T. \& Johnson, J.L. (2008). Individual differences in perceptions of service failure and recovery: the role of race and discriminatory bias. Journal of the Academy of Marketing Science, 552-564.

Bonifield, C, \& Cole, Catherine. (2007). Affective Responses to Service Failure: Anger, Regret, and Retaliatory versus Conciliatory Responses. Marketing Letters, 18, 85-99

Chon, K. W, Shafaghi. M,Woollaston.C, \& Lui, Vincent. (2010). B2B e-marketplace: an e-marketing framework for B2B commerce. Marketing Intelligence \& Planning, 28, 310-329.

Cooper, Donald R., \& Schindler, Pamela S. (2014). Business Research Methods (12 edition). New York: Mc GrawHill/Irwin.

DBS Asian Insights Indonesia. (2018). The Retail Revolution. [online] Available at: https://www.dbsinsights.com/id/digital-dan-inovasi/indonesia-pusat-ecommerce-asean [Accessed 2 Feb. 2018].

Dunning, J., Pecotich, A \& O'Cass, A. (2004). What happens when things go wrong? Retail sales explanations and their effects. Psychology and Marketing, 553-72. 


\section{CUSTOMER COMPLAINT RESPONSE STRATEGY IN SERVICE FAILURE: STUDY OF ONLINE SHOPPER IN INDONESIA}

Forbes.com. (2018). Forbes Welcome. [online] Available at: https://www.forbes.com/sites/richardkestenbaum/2017/04/26/what-are-onlinemarketplaces-and-what-is-their-future/\#34d74ffb3284 [Accessed 4 Feb. 2018].

Hoffman, K.D., Kelley, S.W. \& Rotalsky, H.W. (1995). Tracking service failures and employee recovery efforts. Journal of Services Marketing, 49-61.

Homburg, C. \& Giering, A. (2001). Personal characteristics as moderators of the relationship between customer satisfaction and loyalty - an empirical analysis, Psychology \& Marketing, 18,. 43-66.

Jang, SooCheong \& Kim, Jong-Hyeong (2014).. A Scenario-Based Experiment and Field Study: A Comparative Examination for Service Failure and Recovery. International Journal of Hospitality Management

Jasa, N. (2018). Pola Belanja Masyarakat Alami Pergeseran Cepat. [online] Industri.bisnis.com. Available at: http://industri.bisnis.com/read/20171003/12/695256/pola-belanja-masyarakatalami-pergeseran-cepat [Accessed 1 Feb. 2018].

Kaiser, Susanne. \& Holger, Roschk (2013). The Nature of an apology: An Experimental Study on How to Apologize After A Service Failure. Marketing Letters

Karatepe, O.M. (2006). Customer complaints and organizational responses: the effects of complainants' perceptions of justice on satisfaction and loyalty International. International Journal of Hospitality Management, 69-90.

Liang, T.P., Lin, C.Y. \& Chen, C.N. (2004). Effects of electronic commerce models and industrial characteristics on firm performance. Industrial Management \& Data Systems, 7, 538-45.

Liao, H. (2007). Do it right this time: the role of employee service recovery performance in customer perceived justice and customer loyalty after service failures. Journal of Applied Psychology, 1006-19.

Little, ed \& Ebi Marandi (2003). Relationship Marketing Management ( $1^{\text {st }}$ edition). Thomson Learning

Lovelock, Christhopher \& Jochen Wirtz (2011). Services Marketing : People, Technology, Strategy ( $7^{\text {th }}$ edition). New York: Prentice Hall

Malhotra. (2010). Marketing Research An Applied Orientation (6th ed.). New York: Prentice Hall.

Mattila, A.S. (2006). The power of explanations in mitigating the ill-effects of service failures. Journal of Services Marketing, 422-428.

Mattila, A.S. \& Patterson, P. (2004). Service recovery and fairness perceptions in collectivist and individualist context. Journal of Services Research. 336-46.

McKinsey \& Company. (2018). The evolving Indonesian consumer. [online] Available at: https://www.mckinsey.com/business-functions/marketing-and-sales/ourinsights/the-evolving-indonesian-consumer [Accessed 4 Feb. 2018].

Merina, N. (2018). Data Pengguna Internet di Indonesia 2016, Riset APJII. [online] Media Bisnis UKM Online \& Peluang Usaha. Available at: http://goukm.id/data-pengguna-internet-di-indonesia-2016/ [Accessed 2 Feb. 2018]. 
Nathania, Y. (2018). E-Commerce Meningkat Tajam, Siapa yang Tertinggi?. [online] IDN Times. Available at: https://business.idntimes.com/economy/yoshi/pertumbuhan-e-commerceindonesia-1 [Accessed 2 Feb. 2018].

Oh, Soo Jung \& Kim, Soo Wook. (2011). The effect of B2B e-marketplace type on buyer-supplier relational advantages of e-marketplace and firm performance. Asian Journal on Quality, 12, 189-203.

Prihadi, S. (2018). Peta Persaingan Situs e-Commerce di Indonesia. [online] CNN Indonesia. Available at: https://www.cnnindonesia.com/teknologi/20170315104148-185-200219/petapersaingan-situs-e-commerce-di-indonesia [Accessed 2 Feb. 2018].

Parasuraman, A. (2006). Modeling opportunities in service recovery and customermanaged interactions. Journal of Marketing Science, 590-593.

Shapiro, D.L. (1991). The effects of explanations on negative reactions to deceit. Administrative Science Quarterly, 614-30.

Shapiro, D.L., Buttner, E.H. \& Barry, B. (1994). Explanations: what factors enhance their perceived adequacy?, Organizational Behavior and Human Decision Processes, 59, 346-68.

Shopnielsen.com. (2018). Nielsen Reports and Insights | Indonesia E-Commerce. [online] Available at: http://www.shopnielsen.com/reports/global-e-commercethe-new-retail-report-q3-2014-indonesia-data [Accessed 2 Feb. 2018].

Soares R.R, Zhang, Ting Ting, Proenca, João \& Kandampully, Jay. (2015). Why are generation Y consumers the most likely to complain and repurchase?, Journal of Service Management. 2015.

Sparks, B.A. \& Fredline, E. (2007). Providing an explanation for service failure: context, content and customer responses. Journal of Hospitality and Tourism Research, 241-60.

Sekaran, Uma \& Roger Bougie (2013). Research Methods and for Business (6 $6^{\text {th }}$ edition). Chichester, West Sussex: John Wiley \& Sons

Tarofder, A. K., Nikhashemi, S. R., Azam, S. M. Ferdous., Selvantharan, P., \& Haque, A. (2016).. The Mediating Influence of Service Failure Explanation on Customer Repurchase Intention Through Customers Satisfaction. International Journal of Quality and Service Sciences

Tax, S.S., Brown, S.W \& Chandrashekaran, M. (1998). Customer evaluations of service complaint experiences: implications for relationship marketing. Journal of Marketing, 60-75.

Wang, Chen-ya \& Mattila, A.S. (2011). A cross-cultural comparison of perceived informational fairness with service failure explanations. Journal of Services Marketing, 429-439.

Yang, H.C. (2012), Young american consumers' prior negative experience of online disclosure, online privacy concerns, and privacy protection behavioural intent. Journal of Consumer Satisfaction, Dissatisfaction \& Complaining Behavior, 25, 179-202.

Ye, Q., Law, R., Gu, B. \& Chen, W. (2011). The influence of user-generated content 
on traveler behavior: An empirical investigation on the effects of e-wordofmouth

to hotel online bookings. Computers in Human Behavior, 27, 634-639.

Yun, H., Lee, C.C. \& Kettinger, W.J. (2012). Personal Information Breach as a

Service Failure: Examining Relationships among Recovery Efforts, Justice, and Customer Responses. [online]. available http://aisel.aisnet.org/icis2012/proceedings/ResearchInProgress/22/ [Accessed 30 Juni. 2018). 